\title{
Pengukuran Efektivitas Mesin Menggunakan Overall Equipment Effectiveness Untuk Dasar Usulan Perbaikan
}

\author{
Bernandus Yoseph Bilianto ${ }^{1}$, Yurida Ekawati ${ }^{2}$
}

\begin{abstract}
CV. Gracia has offset printing machines that often have downtime due to engine failures. The low effectiveness of the offset printing machines could cause losses to the company. Overall Equipment Effectiveness (OEE) method is a tool to determine the success rate of Total Productive Maintenance (TPM) based on categories of availability, performance, and quality. The OEE average value of the company in 2014, 57\%, is relatively low. In this study, causes of this low OEE is analyzed using Failure Mode and Effect Analysis (FMEA) and fishbone diagram. Improvements such as relocation of raw material and colourful catalog were subsequently proposed and implemented during April - May 2016. The implementation resulted in OEE average value of $60 \%$.
\end{abstract}

Keywords. total productive maintenance, overall equipment effectiveness, failure mode and effect analysis, fishbone diagram.

\begin{abstract}
Abstrak.CV. Gracia memiliki mesin cetak (offset printing) yang sering mengalami downtime dikarenakan kerusakan mesin. Mesin cetak yang memiliki efektivitas rendah dapat menimbulkan kerugian bagi perusahaan. Metode Overall Equipment Effectiveness (OEE) merupakan alat bantu untuk mengukur tingkat keberhasilan Total Productive Maintenance (TPM) berdasarkan tiga kategori yaitu availability, performance, dan quality. Nilai rata-rata OEE pada tahun 2014 tergolong rendah yaitu sebesar 57\%. Rendahnya nilai OEE dianalisis menggunakan Failure Mode and Effect Analysis (FMEA) dan fishbone diagram untuk mengetahui penyebab permasalahan. Berdasarkan permasalahan tersebut dilakukan penerapan usulan berupa pemindahan lokasi raw material dan pembuatan katalog warna pada bulan April - Mei tahun 2016 untuk meningkatkan efektivitas waktu kerja. Hasil penerapan usulan perbaikan menunjukan nilai rata-rata OEE yang baru adalah sebesar $60 \%$.
\end{abstract}

Kata Kunci. total productive maintenance, overall equipment effectiveness, failure mode and effect analysis, fishbone diagram.

\section{Pendahuluan}

Dewasa ini perkembangan pada sektor industri manufaktur sangat cepat. Hal tersebut membuat persaingan antar perusahaan menjadi semakin ketat. Oleh sebab itu, sebagian besar perusahaan memutuskan untuk menggunakan mesin sebagai alat bantu utama dalam menjalankan proses

\footnotetext{
Bernandus Yoseph Bilianto, Program Studi Teknik Industri, Fakultas Sains dan Teknologi, Universitas Ma Chung, Jl. Villa Puncak Tidar N-01 Malang, (email: bernandusyb@gmail.com)

${ }^{2}$ Yurida Ekawati, Program Studi Teknik Industri, Fakultas Sains dan Teknologi, Universitas Ma Chung, Jl. Villa Puncak Tidar N-01 Malang, (email: yurida.ekawati@machung.ac.id)
}

Diajukan: 02-02-2016

Diperbaiki: 14-11-2016 produksi, dengan harapan jumlah produksi dapat meningkat dan mampu memenuhi seluruh permintaan pasar. CV. Gracia merupakan salah satu contoh perusahaan manufaktur yang sebagian besar prosesnya telah menggunakan mesin. Namun dalam prosesnya beberapa mesin sering digunakan diluar batas normal untuk memenuhi target produksi. Mesin yang sering bekerja diluar batas normal dapat menurunkan kapasitas produksi, menurunkan umur mesin dan, mempercepat penggantian spare part karena rusak.

Mesin cetak (offset printing) di CV. Gracia beberapa kali mengalami hambatan berupa kerusakan mesin, sehingga mengharuskan mesin berhenti beroperasi untuk perbaikan. Kegunaan mesin cetak ini adalah untuk mencetak lembaran kertas kotak rokok (etiket). Adanya kerusakan mesin akan mengakibatkan kapasitas produksi menurun atau terjadi selisih antara target dan realisasi produksi. Pemeliharaan dan perbaikan 
berkala merupakan salah satu upaya yang dapat dilakukan oleh perusahaan untuk menjaga kestabilan produksi.

Penerapan pemeliharaan yang sering dilakukan dalam perusahaan manufaktur adalah total productive maintenance (TPM). Rahmad, dkk (2012) menegaskan bahwa TPM adalah program pemeliharaan yang sering diterapkan oleh perusahaan Jepang. Tingkat keberhasilan penerapan TPM diukur dengan menggunakan metode overall equipment effectiveness (OEE). Menurut Said dan Susetyo (2008), OEE merupakan nilai efektivitas peralatan secara keseluruhan untuk mendapatkan pencapaian performance dan reliability. Pengukuran OEE dilakukan berdasarkan ketiga kategori six big losses, yaitu availability, performance, dan quality. Nilai OEE yang didapatkan lalu dibandingkan dengan nilai OEE dari peralatan dalam kondisi ideal yang merupakan standar dari perusahaan kelas dunia, untuk mengetahui tingkat keberhasilan penerapan TPM.

Berdasarkan masalah yang telah dijabarkan terdahulu, artikel ini menjelaskan tentang: (1) nilai efektivitas dari mesin cetak menggunakan metode OEE, (2) faktor-faktor yang mempengaruhi mesin cetak sehingga memiliki nilai efektivitas rendah, (3) usulan perbaikan yang sesuai dengan permasalahan efektivitas mesin cetak yang rendah, dan (4) capaian nilai efektivitas mesin cetak setelah penerapan usulan perbaikan menggunakan metode OEE.

\section{Metodologi}

Artikel ini didasarkan pada penelitian yang dilakukan dari bulan Februari hingga Juni 2016 di CV. Gracia. Identifikasi masalah dilakukan dengan pengamatan atau observasi secara langsung ke dalam perusahaan. Hal tersebut dilakukan untuk mengetahui permasalahan pada perusahaan tersebut. Permasalahan utama yang akan ditinjau adalah penilaian performansi mesin cetak yang digunakan memproduksi lembaran kertas etiket.

Pengumpulan data menggunakan data primer dan data sekunder. Data primer adalah data yang diperoleh dari hasil pengamatan secara langsung, yaitu jumlah mesin produksi yang digunakan, cara kerja mesin, proses produksi, dan datayang dibutuhkan untuk perhitungan OEE setelah dilakukan penerapan perbaikan. Sedangkan data sekunder adalah data yang diperoleh secara tidak langsung, yaitu nilai standar OEE dan data yang dibutuhkan untuk perhitungan OEE pada tahun 2014 dan 2016.

\section{Perhitungan OEE}

Perhitungan awal dilakukan menggunakan data pada tahun 2014. Menurut Nakajima (1988), perhitungan OEE dilakukan dengan beberapa langkah, yaitu:

1. Perhitungan availability, yaitu rasio yang menunjukkan pemanfaatan waktu yang tersedia untuk kegiatan operasi mesin atau peralatan. Data yang dibutuhkan adalah downtime dan loading time, dengan menggunakan rumus perhitungan berikut:

$$
\text { Availability }=\frac{\text { Loading Time }- \text { Down Time }}{\text { Loading Time }}
$$

2. Perhitungan performance, yaitu rasio yang menunjukkan kemampuan dari peralatan dalam menghasilkan barang. Data yang dibutuhkan adalah total produksi, cycle time, dan operation time, dengan menggunakan rumus perhitungan adalah sebagai berikut:

Performance $=\frac{\text { Total Produksi } \times \text { Ideal Cycle Time }}{\text { Operation Time }}$

3. Perhitungan quality, yaitu rasio yang menunjukkan kemampuan dari peralatan untuk menghasilkan barang sesuai dengan standar yang ditentukan. Data yang dibutuhkan adalah total produksi dan banyaknya defect, dengan menggunakan rumus perhitungan adalah sebagai berikut:

Quality $=\frac{\text { Output Produksi-Reject }}{\text { Output Produksi }}$

4. Perhitungan overall equipment effectiveness (OEE), yang diperoleh dari hasil perkalian ketiga kategori tersebut. Sehingga rumus yang digunakan untuk perhitungan adalah sebagai berikut:

$O E E=$ Availibility $\times$ Performance $\times$ Quality

Analisis lanjut terhadap hasil perhitungan OEE menggunakan metode FMEA. Langkah-langkah penggunaan FMEA:

1. Membuat urutan proses produksi pada mesin cetak untuk mengetahui jenis aktivitas yang berlangsung mulai dari masuknya bahan baku hingga dihasilkannya sebuah produk.

2. Mengidentifikasi masalah menggunakan diagram Ishikawa, yang dilakukan dengan 
mengidentifikasi permasalahan yang terjadi selama proses produksi. Permasalahan yang didapatkan dijabarkan untuk mengetahui akar permasalahannya dengan menggunakan diagram Ishikawa.

3. Memberikan pembobotan, dimana masalah atau kegagalan yang telah didapat dimasukkan kedalam form FMEA. Kemudian dicari efek dari kegagalan tersebut untuk diberi pembobotan pada faktor severity (faktor yang meninjau tingkat efek dari permasalahan). Selanjutnya dicari faktor penyebab terjadinya kegagalan tersebut dan dilakukan pembobotan untuk faktor occurence (faktor yang meninjau frekuensi permasalahan tersebut terjadi) dan detectability (faktor yang meninjau respon yang dapat diberikan untuk mendeteksi kegagalan tersebut).

4. Menghitung nilai risk priority number (RPN) dan penentuan ranking, yang didapatkan dari hasil perkalian ketiga faktor yang telah diberi pembobotan. Akar permasalahan yang mendapat nilai RPN terbesar akan menjadi prioritas utama untuk diselesaikan. Berikut merupakan rumus yang digunakan untuk perhitungan RPN:

$R P N=$ Severity $x$ Occurrence $x$ Detecability

\section{Usulan Perbaikan}

Akar permasalahan yang didapat diberi usulan perbaikan yang sesuai. Beberapa usulan perbaikan akan diterapkan ke dalam perusahaan, dan untuk mengetahui usulan yang memungkinkan untuk diterapkan, penulis melakukan diskusi dengan pihak perusahaan.

Penerapan dilakukan untuk mengetahui apakah usulan perbaikan yang terpilih dapat memberikan dampak positif atau berpengaruh dalam efektivitas dan dapat meningkatkan nilai OEE pada mesin cetak. Penerapan dilakukan dalam jangka waktu dua bulan yaitu bulan April sampai dengan Mei 2016, selama proses penerapan berlangsung peneliti akan melakukan pengamatan dan pengambilan data yang baru untuk melakukan perhitungan nilai OEE yang baru.

Setelah dilakukan penerapan usulan perbaikan didapatkan data produksi loading time, operation time, cycle time, unscheduled downtime, dan banyaknya defect yang baru. Dengan datatersebut dilakukan perhitungan availibility, performance, quality dan nilai OEE yang baru. Hal tersebut dilakukan untuk mengetahui terjadinya perubahan antara sebelum dan sesudah penerapan usulan perbaikan dilakukan.

Berdasarkan hasil perhitungan OEE setelah penerapan usulan perbaikan akan didapatkan nilai OEE yang baru. Pada tahap ini dilakukan perbandingan antara nilai OEE sebelum dengan nilai OEE setelah penerapan usulan perbaikan. Dengan demikian dapat diketahui apakah usulan perbaikan yang dilakukan sudah tepat dan dapat memberikan pengaruh yang baik terhadap kelancaran dan hasil dari proses produksi atau tidak.

\section{HASIL DAN PEMBAHASAN}

\section{Perhitungan Nilai OEE Awal}

Perhitungan dilakukan pada mesin cetak yang digunakan pada CV. Gracia, dimana mesin tersebut merupakan mesin utama yang paling sering beroperasi dan sering mengalami kendala dalam prosesnya. Sebelum melakukan perhitungan OEE, perhitungan dilakukan terhadap kategori penyusunnya, yaitu availability, performance dan quality. Datayang digunakan adalah data pada tahun 2014 yang didapat berdasarkan data historis dari perusahaan.

Tabel 1 menunjukkan hasil rekapitulasi data dan hasil perhitungan untuk kategori availability pada mesin cetak. Data pada Tabel 1 menunjukan bahwa nilai availability adalah sebesar $76 \%$.Namun nilai tersebut masih dibawah nilai standar yang diharapkan, yaitu sebesar $90 \%$.

Tabel 2 menunjukkan hasil rekapitulasi data dan hasil perhitungan kategori performance pada mesin cetak. Data pada Tabel 2 menunjukkan bahwa nilai performance adalah sebesar $79 \%$.Namun nilai tersebut masih dibawah nilai standar yang diharapkan, yaitu sebesar 95\%.

Tabel 3 menunjukkan rekap data dan hasil perhitungan kategori quality pada mesin cetak. Data pada tabel 3. menunjukan bahwa nilai quality sebesar 95\%. Nilai tersebut belum mencapai standar yang diharapkan yaitu sebesar $99 \%$. 
Tabel 1. Data dan hasil perhitungan availability

\begin{tabular}{lcrrrrr}
\hline Bulan & $\begin{array}{c}\text { Standard Time } \\
\text { Available } \\
\text { (menit) }\end{array}$ & $\begin{array}{c}\text { Planned } \\
\text { Downtime } \\
\text { (menit) }\end{array}$ & $\begin{array}{c}\text { Loading } \\
\text { Time } \\
\text { (menit) }\end{array}$ & $\begin{array}{c}\text { Set Up } \\
\text { Time } \\
\text { (menit) }\end{array}$ & $\begin{array}{c}\text { Unscheduled } \\
\text { Downtime } \\
\text { (menit) }\end{array}$ & $\begin{array}{c}\text { \% } \\
\text { Availability }\end{array}$ \\
\hline Januari & 19.680 & 840 & 18.840 & 4.080 & 360 & $76 \%$ \\
Februari & 19.200 & 1.200 & 18.000 & 3.960 & 480 & $75 \%$ \\
Maret & 18.900 & 1.440 & 17.460 & 3.840 & 720 & $74 \%$ \\
April & 20.880 & 1.200 & 19.680 & 3.720 & 360 & $79 \%$ \\
Mei & 20.220 & 840 & 19.380 & 3.720 & 420 & $79 \%$ \\
Juni & 19.260 & 1.800 & 17.460 & 3.960 & 480 & $75 \%$ \\
Juli & 21.360 & 840 & 20.520 & 3.840 & 540 & $79 \%$ \\
Agustus & 16.680 & 1.200 & 15.480 & 3.840 & 240 & $74 \%$ \\
September & 20.280 & 1.440 & 18.840 & 3.780 & 360 & $78 \%$ \\
Oktober & 20.160 & 1.200 & 18.960 & 4.080 & 1.320 & $72 \%$ \\
November & 19.140 & 840 & 18.300 & 3.840 & 360 & $77 \%$ \\
Desember & 16.980 & 1.800 & 15.180 & 3.780 & 120 & $74 \%$ \\
& \multicolumn{7}{c}{ Rata-rata } \\
\hline
\end{tabular}

Tabel 2. Data dan hasil perhitungan performance

\begin{tabular}{lrrrr}
\hline \multicolumn{1}{c}{ Bulan } & $\begin{array}{c}\text { Data } \\
\text { Produksi (kg) }\end{array}$ & $\begin{array}{c}\text { Operation } \\
\text { Time (menit) }\end{array}$ & $\begin{array}{c}\text { Cycle Time } \\
\text { (menit) }\end{array}$ & $\begin{array}{c}\text { \% } \\
\text { Performance }\end{array}$ \\
\hline Januari & 264.050 & 14.400 & 0,043 & $79 \%$ \\
Februari & 257.277 & 13.560 & 0,043 & $81 \%$ \\
Maret & 242.709 & 12.900 & 0,043 & $81 \%$ \\
April & 275.824 & 15.600 & 0,043 & $76 \%$ \\
Mei & 273.619 & 15.240 & 0,043 & $77 \%$ \\
Juni & 244.709 & 13.020 & 0,043 & $81 \%$ \\
Juli & 287.596 & 16.140 & 0,043 & $76 \%$ \\
Agustus & 216.959 & 11.400 & 0,043 & $82 \%$ \\
September & 266.530 & 14.700 & 0,043 & $78 \%$ \\
Oktober & 255.699 & 13.560 & 0,043 & $81 \%$ \\
November & 260.482 & 14.100 & 0,043 & $79 \%$ \\
Desember & 214.754 & 11.280 & 0,043 & $82 \%$ \\
& Rata-rata & & & $\mathbf{7 9 \%}$ \\
\hline
\end{tabular}

Tabel 3. Data dan hasil perhitungan quality

\begin{tabular}{lcrc}
\hline Bulan & $\begin{array}{c}\text { Data } \\
\text { Produksi } \\
(\mathbf{k g})\end{array}$ & $\begin{array}{c}\text { Jumlah } \\
\text { Defect } \\
\mathbf{( k g )}\end{array}$ & $\begin{array}{c}\text { \% } \\
\text { Quality }\end{array}$ \\
\hline Januari & 264.050 & 6.575 & $98 \%$ \\
Februari & 257.277 & 8.318 & $97 \%$ \\
Maret & 242.709 & 15.266 & $94 \%$ \\
April & 275.824 & 15.915 & $94 \%$ \\
Mei & 273.619 & 16.976 & $94 \%$ \\
Juni & 244.709 & 18.916 & $92 \%$ \\
Juli & 287.596 & 6.040 & $98 \%$ \\
Agustus & 216.959 & 7.331 & $97 \%$ \\
September & 266.530 & 21.842 & $92 \%$ \\
Oktober & 255.699 & 5.399 & $98 \%$ \\
November & 260.482 & 13.905 & $95 \%$ \\
Desember & 214.754 & 7.319 & $97 \%$ \\
& Rata-rata & & $95 \%$ \\
\hline
\end{tabular}

Setelah ketiga kategori penyusun OEE didapatkan, maka dapat dilakukan perhitungan nilai OEE. Tabel 4 menunjukkan hasil perhitungan
OEE pada mesin cetak. Nilai OEE adalah sebesar $57 \%$, namun nilai tersebut masih dibawah nilai standar yang diharapkan yaitu sebesar $85 \%$. 
Tabel 4. Data dan hasil perhitunganOEE

\begin{tabular}{lcccc}
\hline \multicolumn{1}{c}{ Bulan } & $\begin{array}{c}\% \\
\text { Availability }\end{array}$ & $\begin{array}{c}\% \\
\text { Performance }\end{array}$ & $\begin{array}{c}\text { Quality } \\
\text { Quar }\end{array}$ & OEE \\
\hline Januari & $76 \%$ & $79 \%$ & $98 \%$ & $59 \%$ \\
Februari & $75 \%$ & $81 \%$ & $97 \%$ & $59 \%$ \\
Maret & $74 \%$ & $81 \%$ & $94 \%$ & $56 \%$ \\
April & $79 \%$ & $76 \%$ & $94 \%$ & $57 \%$ \\
Mei & $79 \%$ & $77 \%$ & $94 \%$ & $57 \%$ \\
Juni & $75 \%$ & $81 \%$ & $92 \%$ & $55 \%$ \\
Juli & $79 \%$ & $76 \%$ & $98 \%$ & $59 \%$ \\
Agustus & $74 \%$ & $82 \%$ & $97 \%$ & $58 \%$ \\
September & $78 \%$ & $78 \%$ & $92 \%$ & $56 \%$ \\
Oktober & $72 \%$ & $81 \%$ & $98 \%$ & $57 \%$ \\
November & $77 \%$ & $79 \%$ & $95 \%$ & $58 \%$ \\
Desember & $74 \%$ & $82 \%$ & $97 \%$ & $59 \%$ \\
Rata-rata & $\mathbf{7 6 \%}$ & $\mathbf{7 9 \%}$ & $\mathbf{9 5 \%}$ & $\mathbf{5 7 \%}$ \\
\hline
\end{tabular}

Nilai rata-rata OEE pada mesin cetak di CV Gracia pada tahun 2014 didapatkan hasil sebesar $57 \%$ dengan nilai availability, performance dan quality secara berturut-turut adalah $76 \%, 79 \%$ dan $95 \%$. Nilai tersebut masih dapat dikatakan baik untuk tolok ukur perusahaan manufaktur di Indonesia, namun apabila dibandingkan dengan standar yang telah ditetapkan pada kelas dunia nilai tersebut masih jauh dibawah standar. Hal tersebut menunjukan bahwa perusahaan masih membutuhkan improvement, terlebih pada kategori availability yang memiliki nilai terendah. Sebelum melakukan improvement harus diketahui terlebih dahulu permasalahan yang terjadi, sehingga perusahaan mampu memberikan penanganan dengan tepat.

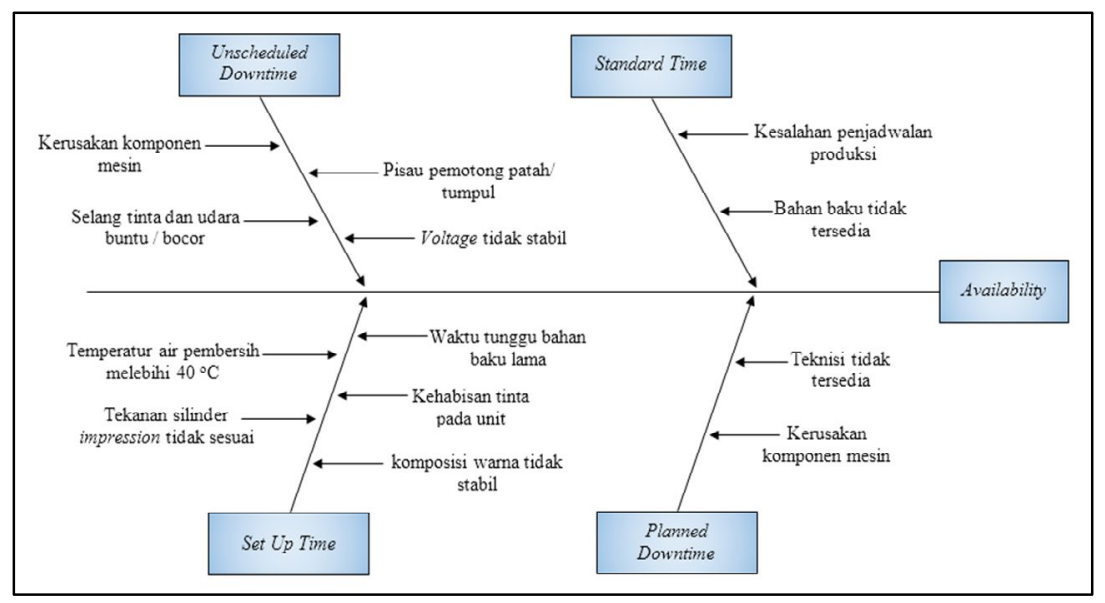

Gambar 1. Diagram Ishikawa dengan pokok permasalahan availability

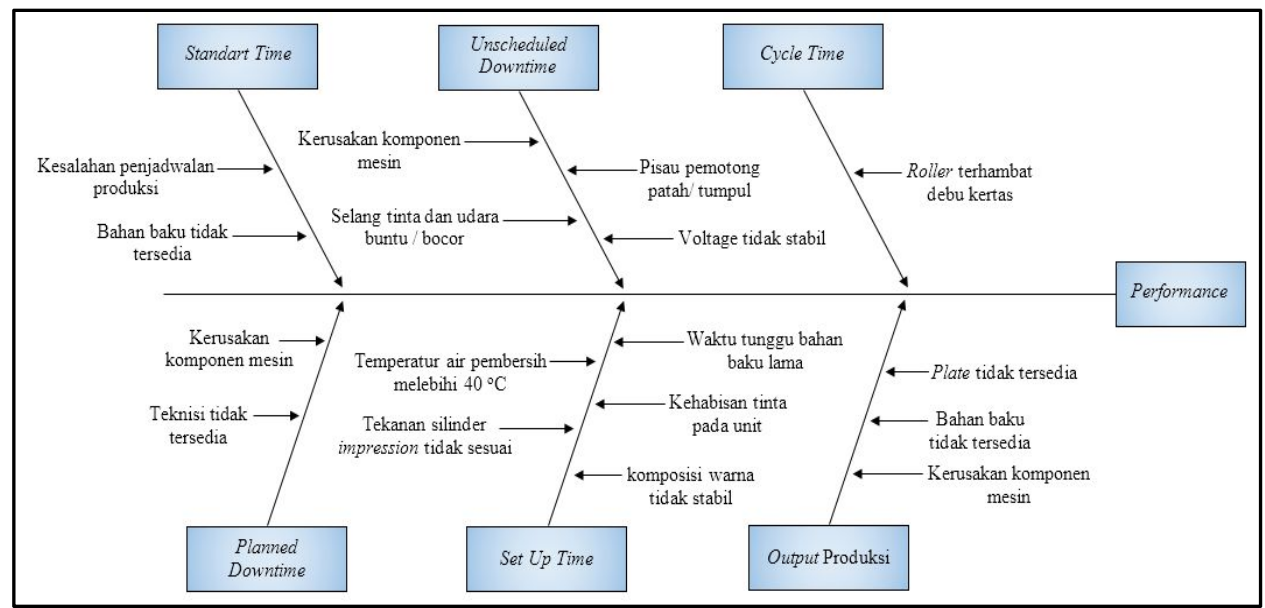

Gambar 2. Diagram Ishikawa dengan pokok permasalahan performance 


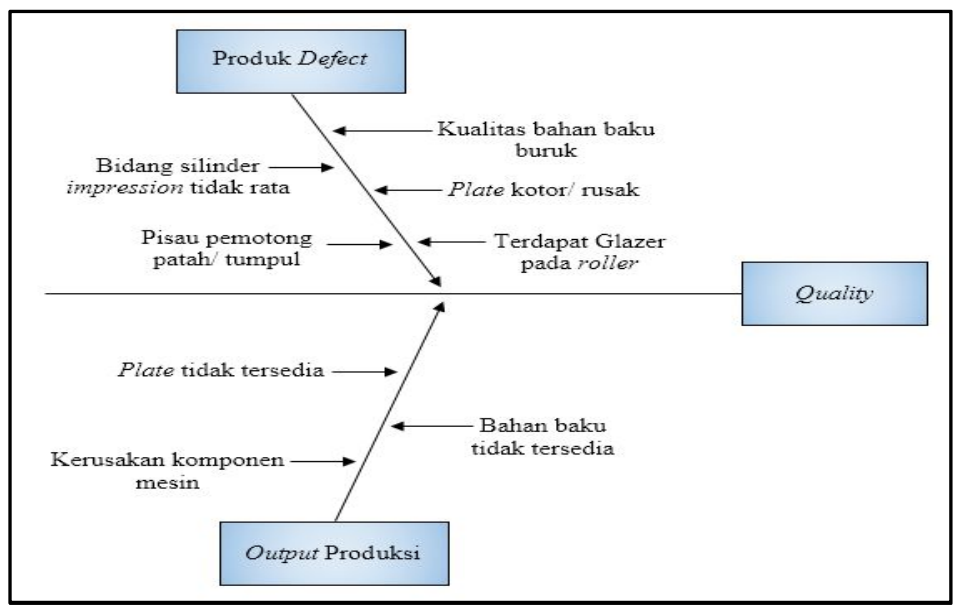

Gambar 3. Diagram Ishikawa dengan pokok permasalahan Quality

\section{Identifikasi masalah dengan diagram Ishikawa}

Perbaikan dilakukan setelah mengetahui akar permasalahan yang menyebabkan mesin tidak bekerja dengan maksimal atau nilai OEE menjadi rendah. Diagram Ishikawa digunakan untuk mengidentifikasi akar permasalahan, sedangkan untuk pokok permasalahanadalah ketiga kategori penyusun OEE yaitu availability, performance, dan quality.

Gambar 1 memperlihatkan diagram Ishikawa dengan pokok masalah availability. Gambar 2 memperlihatkan diagram Ishikawa dengan pokok masalah performance. Gambar 3 memperlihatkan diagram Ishikawa dengan pokok masalah quality.

Identifikasi masalah menunjukkan bahwa terdapat 34 jenis potensi kegagalan dengan 39 efek kegagalan dan 44 penyebab kegagalan. Hal tersebut yang menyebabkan rendahnya nilai OEE. Pengisian form FMEA memberikan pembobotan terhadap faktor severity, occurrence dan detectability. Hasil dari pembobotan tersebut akan menentukan akar masalah yang menjadi prioritas utama.

Pembobotan faktor severity dilakukan dengan menggunakan skala 1 sampai 10, berdasartingkat efek dari kegagalan yang terjadi. Semakin tinggi angka yang diberikan maka semakin berat efek dari kegagalannya. Pembobotan faktor occurrence dilakukan dengan menggunakan skala $1-10$, berdasarkan frekuensi terjadinya kegagalan. Semakin tinggi angka yang diberikan berarti kegagalan sering terjadi.

Pembobotan faktor detectability dilakukan dengan menggunakan skala $1-10$, berdasar tingkat kesulitan dalam mengetahui terjadinya kegagalan. Semakin tinggi angka yang diberikan, maka semakin sulit kegagalan tersebut diketahui.

Setelah didapatkan nilai pembobotan dari faktor severity, occurrence, dan detectability dari masing-masing kegagalan, selanjutnya dilakukan perhitungan RPN. Nilai RPN digunakan untuk mengetahui kegagalan yang akan menjadi prioritas utama. Semakin tinggi nilai RPN dari kegagalan itu maka kegagalan tersebut menjadi prioritas utama bagi perusahaan untuk diperbaiki. RPN didapatkan dari hasil perkalian nilai severity, occurrence dan detectability. Hasil perhitungan RPN dan ranking dari tiap kegagalan yang telah diidentifikasi, diperlihatkan pada Tabel 5 .

\section{Usulan Perbaikan}

Berdasarkan akar permasalahan yang telah diidentifikasi dan diberi ranking prioritas kegagalan, maka disusunlah beberapa solusi perbaikan untuk setiap akar permasalalahan. Usulan perbaikan ini nantinya digunakan sebagai bahan pertimbangan bagi perusahaan untuk melakukan perbaikan.

Usulan perbaikan dari setiap akar permasalahan berjumlah 44 solusi, dimana setelah melewati tahap pembobotan FMEA setiap akar permasalahan memiliki prioritas mulai dari yang utama hingga yang akhir untuk diberikan perbaikan. Berdasarkan diskusi yang telah dilakukan dengan pihak perusahaan terpilih dua usulan perbaikan yang akan diterapkan, dimana kedua usulan yang terpilih diperuntukan menangani masalah set up time yang terlalu lama. 
Tabel 5. Hasil perhitungan RPN dan ranking

\begin{tabular}{|c|c|c|c|c|c|}
\hline $\begin{array}{c}\text { Potential Failure } \\
\text { Mode }\end{array}$ & $\begin{array}{c}\text { Potential Effects of } \\
\text { Failure }\end{array}$ & $\begin{array}{c}\text { Potential Cause } \\
\text { of Failure }\end{array}$ & $\begin{array}{l}\text { Penanganan yang } \\
\text { sudah dilakukan }\end{array}$ & RPN & Rank \\
\hline $\begin{array}{l}\text { Roller terhambat } \\
\text { debu kertas }\end{array}$ & $\begin{array}{l}\text { Kecepatan mesin untuk } \\
\text { produksi menurun }\end{array}$ & $\begin{array}{l}\text { Debu kertas yang } \\
\text { terpotong }\end{array}$ & $\begin{array}{l}\text { Melakukan } \\
\text { pembersihan mesin } \\
\text { secara rutin }\end{array}$ & 294 & 1 \\
\hline Voltage tidak stabil & $\begin{array}{l}\text { Sistem elektronik dan } \\
\text { komponen penggerak } \\
\text { rusak }\end{array}$ & $\begin{array}{l}\text { Pemadaman listrik } \\
\text { bergilir }\end{array}$ & Belum ada penanganan & 240 & 2 \\
\hline $\begin{array}{l}\text { Temperatur air } \\
\text { pembersih } \\
\text { melebihi } 40 \text { oC }\end{array}$ & $\begin{array}{l}\text { Mesin berhenti karena } \\
\text { mengalami overheat }\end{array}$ & Kesalahan pekerja & $\begin{array}{l}\text { Pemantauan secara } \\
\text { rutin }\end{array}$ & 240 & 3 \\
\hline $\begin{array}{l}\text { Temperatur air } \\
\text { pembersih } \\
\text { melebihi } 40 \text { oC }\end{array}$ & Plate cetak rusak & Kesalahan pekerja & $\begin{array}{l}\text { Pemantauan secara } \\
\text { rutin }\end{array}$ & 240 & 4 \\
\hline $\begin{array}{l}\text { Komposisi warna } \\
\text { yang tidak stabil }\end{array}$ & $\begin{array}{l}\text { Waktu kerja mesin } \\
\text { terbuang untuk set up } \\
\text { warna }\end{array}$ & $\begin{array}{l}\text { Belum adanya } \\
\text { standar komposisi } \\
\text { warna }\end{array}$ & Belum ada penanganan & 210 & 5 \\
\hline $\begin{array}{l}\text { Gear penggerak } \\
\text { aus atau patah }\end{array}$ & $\begin{array}{l}\text { Mesin berhenti } \\
\text { beroperasi atau } \\
\text { mengalami downtime }\end{array}$ & Listrik padam & Belum ada penanganan & 160 & 6 \\
\hline $\begin{array}{l}\text { Terdapat glaze } \\
\text { pada roller }\end{array}$ & Kertas sobek & Tinta kering & $\begin{array}{l}\text { Melakukan preventive } \\
\text { maintenance }\end{array}$ & 120 & 7 \\
\hline $\begin{array}{l}\text { Plate rusak atau } \\
\text { kotor }\end{array}$ & $\begin{array}{l}\text { Menghasilkan produk } \\
\text { defect }\end{array}$ & $\begin{array}{l}\text { Suhu air } \\
\text { pembersih diatas } \\
40 \text { oC }\end{array}$ & $\begin{array}{l}\text { Pemantauan secara } \\
\text { rutin }\end{array}$ & 90 & 8 \\
\hline Plate tidak tersedia & $\begin{array}{l}\text { Mesin berhenti } \\
\text { beroperasi atau } \\
\text { mengalami downtime }\end{array}$ & Desain belum jadi & Belum ada penanganan & 80 & 9 \\
\hline $\begin{array}{l}\text { Tekanan silinder } \\
\text { impression tidak } \\
\text { sesuai }\end{array}$ & $\begin{array}{l}\text { Mesin berhenti karena } \\
\text { kertas tidak tertekan } \\
\text { dengan sempurna }\end{array}$ & Kesalahan pekerja & $\begin{array}{l}\text { Pemantauan secara } \\
\text { rutin }\end{array}$ & 75 & 10 \\
\hline $\begin{array}{l}\text { Pisau potong patah } \\
\text { atau tumpul }\end{array}$ & $\begin{array}{l}\text { Kertas tidak terpotong } \\
\text { dengan sempurna } \\
(\text { defect })\end{array}$ & Kesalahan pekerja & $\begin{array}{l}\text { Memberikan } \\
\text { pengarahan sebelum } \\
\text { melakukan pekerjaan }\end{array}$ & 70 & 11 \\
\hline Motor head rusak & $\begin{array}{l}\text { Mesin berhenti } \\
\text { beroperasi atau } \\
\text { mengalami downtime }\end{array}$ & $\begin{array}{l}\text { Melakukan } \\
\text { preventive } \\
\text { maintenance }\end{array}$ & $\begin{array}{l}\text { Melakukan preventive } \\
\text { maintenance }\end{array}$ & 48 & 12 \\
\hline $\begin{array}{l}\text { Lampu indikator } \\
\text { suhu air mati }\end{array}$ & $\begin{array}{l}\text { Tidak dapat melakukan } \\
\text { pemantauan suhu air } \\
\text { pembersih }\end{array}$ & $\begin{array}{l}\text { Penggantian rutin } \\
\text { spare part tidak } \\
\text { terlaksana }\end{array}$ & $\begin{array}{l}\text { Melakukan preventive } \\
\text { maintenance }\end{array}$ & 40 & 13 \\
\hline $\begin{array}{l}\text { Waktu tunggu } \\
\text { bahan baku lama }\end{array}$ & $\begin{array}{l}\text { Mesin mengalami idle } \\
\text { atau waktu kerja mesin } \\
\text { tidak maksimal }\end{array}$ & $\begin{array}{l}\text { Letak gudang } \\
\text { bahan baku jauh } \\
\text { dari mesin } \\
\text { produksi }\end{array}$ & $\begin{array}{l}\text { Membuat jurnal } \\
\text { aktivitas mesin }\end{array}$ & 40 & 14 \\
\hline $\begin{array}{l}\text { Bidang silinder } \\
\text { impression tidak } \\
\text { rata }\end{array}$ & $\begin{array}{l}\text { Struktur kertas } \\
\text { bergelombang }\end{array}$ & $\begin{array}{l}\text { Material kertas } \\
\text { yang berkerak } \\
\text { atau terlipat }\end{array}$ & $\begin{array}{l}\text { Melakukan preventive } \\
\text { maintenance }\end{array}$ & 36 & 15 \\
\hline
\end{tabular}


Tabel 5. Hasil perhitungan RPN dan ranking (lanjutan)

\begin{tabular}{|c|c|c|c|c|c|}
\hline $\begin{array}{c}\text { Potential Failure } \\
\text { Mode }\end{array}$ & $\begin{array}{c}\text { Potential Effects of } \\
\text { Failure }\end{array}$ & $\begin{array}{c}\text { Potential Cause } \\
\text { of Failure }\end{array}$ & $\begin{array}{l}\text { Penanganan yang } \\
\text { sudah dilakukan }\end{array}$ & RPN & Rank \\
\hline Selang tinta buntu & $\begin{array}{l}\text { Proses pewarnaan pada } \\
\text { mesin terhenti }\end{array}$ & $\begin{array}{l}\text { Kerak tinta pada } \\
\text { selang }\end{array}$ & $\begin{array}{l}\text { Pemantauan secara } \\
\text { rutin }\end{array}$ & 36 & 16 \\
\hline $\begin{array}{l}\text { Plate rusak atau } \\
\text { kotor }\end{array}$ & $\begin{array}{l}\text { Menghasilkan produk } \\
\text { defect }\end{array}$ & $\begin{array}{l}\text { Tinta terlalu } \\
\text { kental }\end{array}$ & $\begin{array}{l}\text { Pemantauan secara } \\
\text { rutin }\end{array}$ & 36 & 17 \\
\hline $\begin{array}{l}\text { Roller macet atau } \\
\text { rusak }\end{array}$ & $\begin{array}{l}\text { Mesin berhenti } \\
\text { beroperasi }\end{array}$ & $\begin{array}{l}\text { Pembersihan rutin } \\
\text { pada roller tidak } \\
\text { berjalan }\end{array}$ & $\begin{array}{l}\text { Melakukan } \\
\text { pembersihan rutin }\end{array}$ & 35 & 18 \\
\hline $\begin{array}{l}\text { Rantai penggerak } \\
\text { kendor }\end{array}$ & $\begin{array}{l}\text { Pergerakan mesin tidak } \\
\text { sesuai }\end{array}$ & $\begin{array}{l}\text { Pengecekan rutin } \\
\text { tidak terlaksana }\end{array}$ & $\begin{array}{l}\text { Melakukan preventive } \\
\text { maintenance }\end{array}$ & 32 & 19 \\
\hline Motor head rusak & $\begin{array}{l}\text { Mesin berhenti } \\
\text { beroperasi atau } \\
\text { mengalami downtime }\end{array}$ & $\begin{array}{l}\text { Penggunaan } \\
\text { mesin berlebihan } \\
\text { atau mesin sering } \\
\text { overheat }\end{array}$ & $\begin{array}{l}\text { Melakukan preventive } \\
\text { maintenance }\end{array}$ & 32 & 20 \\
\hline Selang tinta bocor & $\begin{array}{l}\text { Mesin berhenti agar tinta } \\
\text { tidak menyebar ke } \\
\text { seluruh bagian mesin }\end{array}$ & $\begin{array}{l}\text { Selang tertusuk } \\
\text { benda tajam }\end{array}$ & $\begin{array}{l}\text { Pemantauan secara } \\
\text { rutin }\end{array}$ & 30 & 21 \\
\hline $\begin{array}{l}\text { Lampu indikator } \\
\text { tinta mati }\end{array}$ & $\begin{array}{l}\text { Tidak dapat melakukan } \\
\text { pemantauan isi tinta }\end{array}$ & $\begin{array}{l}\text { Penggantian rutin } \\
\text { spare part tidak } \\
\text { terlaksana }\end{array}$ & $\begin{array}{l}\text { Melakukan preventive } \\
\text { maintenance }\end{array}$ & 30 & 22 \\
\hline $\begin{array}{l}\text { Terdapat glaze } \\
\text { pada roller }\end{array}$ & $\begin{array}{l}\text { Menghasilkan produk } \\
\text { defect }\end{array}$ & $\begin{array}{l}\text { Media pembersih } \\
\text { kotor }\end{array}$ & $\begin{array}{l}\text { Pemantauan secara } \\
\text { rutin }\end{array}$ & 30 & 23 \\
\hline $\begin{array}{l}\text { Tuas penggerak } \\
\text { patah }\end{array}$ & $\begin{array}{l}\text { Mesin berhenti } \\
\text { beroperasi atau } \\
\text { mengalami downtime }\end{array}$ & Kesalahan pekerja & $\begin{array}{l}\text { Melakukan preventive } \\
\text { maintenance }\end{array}$ & 28 & 24 \\
\hline $\begin{array}{l}\text { Roller macet atau } \\
\text { rusak }\end{array}$ & $\begin{array}{l}\text { Kecepatan produksi } \\
\text { mesin menurun }\end{array}$ & $\begin{array}{l}\text { Pembersihan rutin } \\
\text { pada roller tidak } \\
\text { berjalan }\end{array}$ & $\begin{array}{l}\text { Melakukan preventive } \\
\text { maintenance }\end{array}$ & 27 & 25 \\
\hline $\begin{array}{l}\text { Pisau potong patah } \\
\text { atau tumpul }\end{array}$ & $\begin{array}{l}\text { Kertas tidak terpotong } \\
\text { dengan sempurna } \\
(\text { defect })\end{array}$ & $\begin{array}{l}\text { Pisau potong } \\
\text { memiliki kualitas } \\
\text { buruk }\end{array}$ & $\begin{array}{l}\text { Melakukan preventive } \\
\text { maintenance }\end{array}$ & 20 & 26 \\
\hline Selang udara bocor & $\begin{array}{l}\text { Proses distribusi material } \\
\text { tidak terlaksana }\end{array}$ & $\begin{array}{l}\text { Selang tertusuk } \\
\text { benda tajam }\end{array}$ & $\begin{array}{l}\text { Pemantauan secara } \\
\text { rutin }\end{array}$ & 20 & 27 \\
\hline Selang tinta bocor & $\begin{array}{l}\text { Mesin berhenti agar tinta } \\
\text { tidak menyebar ke } \\
\text { seluruh bagian mesin }\end{array}$ & $\begin{array}{l}\text { Kesalahan } \\
\text { pemasangan }\end{array}$ & $\begin{array}{l}\text { Memberikan } \\
\text { pengarahan sebelum } \\
\text { melakukan pekerjaan }\end{array}$ & 18 & 28 \\
\hline $\begin{array}{l}\text { Teknisi tidak } \\
\text { tersedia }\end{array}$ & $\begin{array}{l}\text { Mesin mengalami } \\
\text { downtime }\end{array}$ & $\begin{array}{l}\text { Perbaikan } \\
\text { mendadak }\end{array}$ & $\begin{array}{l}\text { Membuat peraturan } \\
\text { mengenai absen kerja }\end{array}$ & 16 & 29 \\
\hline Motor head rusak & $\begin{array}{l}\text { Mesin berhenti } \\
\text { beroperasi atau } \\
\text { mengalami downtime }\end{array}$ & $\begin{array}{l}\text { Melakukan } \\
\text { preventive } \\
\text { maintenance }\end{array}$ & $\begin{array}{l}\text { Melakukan preventive } \\
\text { maintenance }\end{array}$ & 16 & 30 \\
\hline $\begin{array}{l}\text { Gear penggerak } \\
\text { aus atau patah }\end{array}$ & $\begin{array}{l}\text { Mesin berhenti } \\
\text { beroperasi atau } \\
\text { mengalami downtime }\end{array}$ & $\begin{array}{l}\text { Penggantian rutin } \\
\text { spare part tidak } \\
\text { terlaksana }\end{array}$ & $\begin{array}{l}\text { Melakukan preventive } \\
\text { maintenance }\end{array}$ & 16 & 31 \\
\hline
\end{tabular}


Tabel 5. Hasil perhitungan RPN dan ranking (lanjutan)

\begin{tabular}{|c|c|c|c|c|c|}
\hline $\begin{array}{c}\text { Potential Failure } \\
\text { Mode }\end{array}$ & $\begin{array}{c}\text { Potential Effects of } \\
\text { Failure }\end{array}$ & $\begin{array}{l}\text { Potential Cause } \\
\text { of Failure }\end{array}$ & $\begin{array}{l}\text { Penanganan yang } \\
\text { sudah dilakukan }\end{array}$ & RPN & Rank \\
\hline $\begin{array}{l}\text { Feed tray macet } \\
\text { atau rusak }\end{array}$ & $\begin{array}{l}\text { Posisi material berubah- } \\
\text { ubah }\end{array}$ & $\begin{array}{l}\text { Kesalahan } \\
\text { pemasangan } \\
\text { operator }\end{array}$ & $\begin{array}{l}\text { Melakukan preventive } \\
\text { maintenance }\end{array}$ & 16 & 32 \\
\hline Kehabisan tinta & $\begin{array}{l}\text { Produk yang dihasilkan } \\
\text { tidak sesuai }\end{array}$ & $\begin{array}{l}\text { Kurangnya } \\
\text { pemantauan } \\
\text { pekerja }\end{array}$ & $\begin{array}{l}\text { Pemantauan secara } \\
\text { rutin }\end{array}$ & 15 & 33 \\
\hline $\begin{array}{l}\text { Teknisi tidak } \\
\text { tersedia }\end{array}$ & $\begin{array}{l}\text { Perencanaan perbaikan } \\
\text { mesin tidak dapat } \\
\text { terlaksana }\end{array}$ & $\begin{array}{l}\text { Teknisi tidak } \\
\text { masuk kerja }\end{array}$ & $\begin{array}{l}\text { Membuat peraturan } \\
\text { mengenai absen kerja }\end{array}$ & 14 & 34 \\
\hline $\begin{array}{l}\text { Solenoid valve } \\
\text { rusak }\end{array}$ & $\begin{array}{l}\text { Aliran air pendingin } \\
\text { mesin terhambat }\end{array}$ & $\begin{array}{l}\text { Endapan yang } \\
\text { berlebih }\end{array}$ & $\begin{array}{l}\text { Melakukan preventive } \\
\text { maintenance }\end{array}$ & 12 & 35 \\
\hline Selang udara bocor & $\begin{array}{l}\text { Proses distribusi material } \\
\text { tidak terlaksana }\end{array}$ & $\begin{array}{l}\text { Kesalahan } \\
\text { pemasangan }\end{array}$ & $\begin{array}{l}\text { Memberikan } \\
\text { pengarahan sebelum } \\
\text { melakukan pekerjaan }\end{array}$ & 12 & 36 \\
\hline $\begin{array}{l}\text { Roller air macet } \\
\text { atau rusak }\end{array}$ & $\begin{array}{l}\text { Silinder blanket dan plate } \\
\text { kotor }\end{array}$ & $\begin{array}{l}\text { Pembersihan rutin } \\
\text { pada roller tidak } \\
\text { berjalan }\end{array}$ & $\begin{array}{l}\text { Melakukan preventive } \\
\text { maintenance }\end{array}$ & 12 & 37 \\
\hline $\begin{array}{l}\text { Kualitas bahan } \\
\text { baku buruk }\end{array}$ & $\begin{array}{l}\text { Menghasilkan produk } \\
\text { yang tidak sesuai kriteria } \\
\text { perusahaan }\end{array}$ & $\begin{array}{l}\text { Berganti-ganti } \\
\text { supplier }\end{array}$ & $\begin{array}{l}\text { Melakukan } \\
\text { pengecekan pada setiap } \\
\text { bahan baku yang } \\
\text { masuk }\end{array}$ & 12 & 38 \\
\hline $\begin{array}{l}\text { Per pada silinder } \\
\text { rusak }\end{array}$ & $\begin{array}{l}\text { Kertas terjepit pada } \\
\text { silinder }\end{array}$ & $\begin{array}{l}\text { Penggantian rutin } \\
\text { spare part tidak } \\
\text { terlaksana }\end{array}$ & $\begin{array}{l}\text { Melakukan preventive } \\
\text { maintenance }\end{array}$ & 10 & 39 \\
\hline $\begin{array}{l}\text { Hand wheel macet } \\
\text { atau rusak }\end{array}$ & $\begin{array}{l}\text { Tidak dapat mengatur } \\
\text { kedudukan material }\end{array}$ & Tuas berkarat & $\begin{array}{l}\text { Melakukan preventive } \\
\text { maintenance }\end{array}$ & 5 & 40 \\
\hline $\begin{array}{l}\text { Kesalahan } \\
\text { penjadwalan } \\
\text { produksi }\end{array}$ & $\begin{array}{l}\text { Perubahan standard time } \\
\text { untuk waktu kerja mesin }\end{array}$ & $\begin{array}{l}\text { Salah melakukan } \\
\text { perhitungan } \\
\text { forecast }\end{array}$ & $\begin{array}{l}\text { Menyesuaikan } \\
\text { penjadwalan produksi } \\
\text { dengan permintaan } \\
\text { bulanan }\end{array}$ & 4 & 41 \\
\hline $\begin{array}{l}\text { Kesalahan } \\
\text { penjadwalan } \\
\text { produksi }\end{array}$ & $\begin{array}{l}\text { Perubahan standard time } \\
\text { untuk waktu kerja mesin }\end{array}$ & $\begin{array}{l}\text { Penggunaan data } \\
\text { yang belum } \\
\text { diperbaharui }\end{array}$ & $\begin{array}{l}\text { Menyesuaikan } \\
\text { penjadwalan produksi } \\
\text { dengan permintaan } \\
\text { bulanan }\end{array}$ & 4 & 42 \\
\hline Master rail rusak & $\begin{array}{l}\text { Proses distribusi material } \\
\text { terhenti }\end{array}$ & $\begin{array}{l}\text { Penggantian rutin } \\
\text { spare part tidak } \\
\text { terlaksana }\end{array}$ & $\begin{array}{l}\text { Melakukan preventive } \\
\text { maintenance }\end{array}$ & 3 & 43 \\
\hline Selang udara buntu & $\begin{array}{l}\text { Proses distribusi material } \\
\text { tidak terlaksana }\end{array}$ & $\begin{array}{l}\text { Tersumbat debu } \\
\text { kertas }\end{array}$ & $\begin{array}{l}\text { Pemantauan secara } \\
\text { rutin }\end{array}$ & 3 & 44 \\
\hline $\begin{array}{l}\text { Bahan baku tidak } \\
\text { tersedia }\end{array}$ & $\begin{array}{l}\text { Waktu kerja mesin tidak } \\
\text { sesuai dengan standard } \\
\text { yang telah ditentukan }\end{array}$ & $\begin{array}{l}\text { Salah perhitungan } \\
\text { persediaan }\end{array}$ & $\begin{array}{l}\text { Pengecekan persediaan } \\
\text { secara rutin }\end{array}$ & 2 & 45 \\
\hline $\begin{array}{l}\text { Bahan baku tidak } \\
\text { tersedia }\end{array}$ & Output tidak sesuai target & $\begin{array}{l}\text { Keterlambatan } \\
\text { pengiriman }\end{array}$ & $\begin{array}{l}\text { Pengecekan persediaan } \\
\text { secara rutin }\end{array}$ & 2 & 46 \\
\hline
\end{tabular}


Tabel 6. Data dan hasil perhitungan availability baru

\begin{tabular}{lcccccc}
\hline Bulan & $\begin{array}{c}\text { Standard Time } \\
\text { Available } \\
\text { (menit) }\end{array}$ & $\begin{array}{c}\text { Planned } \\
\text { Downtime } \\
\text { (menit) }\end{array}$ & $\begin{array}{c}\text { Loading } \\
\text { Time } \\
\text { (menit) }\end{array}$ & $\begin{array}{c}\text { Set Up } \\
\text { Time } \\
\text { (menit) }\end{array}$ & $\begin{array}{c}\text { Unscheduled } \\
\text { Downtime } \\
\text { (menit) }\end{array}$ & $\begin{array}{c}\% \\
\text { Availability }\end{array}$ \\
\hline April & 20.940 & 1.200 & 19.740 & 3.120 & 720 & $81 \%$ \\
Mei & 19.380 & 840 & 18.540 & 2.803 & 840 & $80 \%$ \\
& \multicolumn{7}{c}{ Rata-rata } \\
\hline
\end{tabular}

Tabel 7. Data dan hasil perhitungan performance baru

\begin{tabular}{lcrrr}
\hline Bulan & $\begin{array}{c}\text { Data Produksi } \\
\text { (kg) }\end{array}$ & $\begin{array}{c}\text { Operation } \\
\text { Time (menit) }\end{array}$ & $\begin{array}{c}\text { Cycle Time } \\
\text { (menit) }\end{array}$ & $\begin{array}{c}\text { \% } \\
\text { Performance }\end{array}$ \\
\hline April & 290.824 & 15.900 & 0,043 & $78 \%$ \\
Mei & 277.931 & 14.897 & 0,043 & $80 \%$ \\
Rata-rata & & & & $79 \%$ \\
\hline
\end{tabular}

Tabel 8. Data dan hasil perhitungan qualitybaru

\begin{tabular}{lccc}
\hline Bulan & $\begin{array}{c}\text { Data Produksi } \\
(\mathbf{k g})\end{array}$ & $\begin{array}{c}\text { Jumlah } \\
\text { Defect (kg) }\end{array}$ & $\begin{array}{c}\text { \% } \\
\text { Quality }\end{array}$ \\
\hline April & 290.824 & 18.671 & $94 \%$ \\
Mei & 277.931 & 15.203 & $95 \%$ \\
Rata-rata & & & $94 \%$ \\
\hline
\end{tabular}

Tabel 9. Hasil perhitungan komponen OEE baru

\begin{tabular}{lcccc}
\hline \multicolumn{1}{c}{ Bulan } & $\begin{array}{c}\text { \% } \\
\text { Availability }\end{array}$ & $\begin{array}{c}\% \\
\text { Performance }\end{array}$ & $\begin{array}{c}\% \\
\text { Quality }\end{array}$ & OEE \\
\hline April & $81 \%$ & $78 \%$ & $94 \%$ & $59 \%$ \\
Mei & $80 \%$ & $80 \%$ & $95 \%$ & $60 \%$ \\
Rata-rata & $80 \%$ & $79 \%$ & $94 \%$ & $60 \%$ \\
\hline
\end{tabular}

Kedua usulan perbaikan yang terpilih adalah:

1. Memindahkan beberapa bahan baku yang dibutuhkan pada tempat yang lebih dekat dengan mesin produksi.

2. Membuat katalog warna yang akan digunakan sebagai acuan bagi pelanggan maupun operator dalam mengatur warna.

Selama proses penerapan usulan perbaikan peneliti melakukan pengamatan secara langsung untuk mendapatkan data-data yang dibutuhkan untuk melakukan perhitungan OEE yang baru. Selain itu data juga didapatkan dari rekap data yang dilakukan oleh operator mesin.

Berdasarkan data pengamatan, Tabel 6 menunjukkan rekapitulasi data dan perhitungan untuk availability yang baru. Tabel 6 menunjukkan nilai availability sebesar $80 \%$, dimana nilai tersebut lebih baik daripada nilai availability sebelum penerapan usulan perbaikan. Pemindahan lokasi bahan baku dan pembuatan katalog akan membuat waktu untuk persiapan akan berkurang, sehingga waktu kerja dapat dibuat lebih efektif.

Perhitungan performance baru dilakukan berdasar data pengamatan yang didapatkan. Tabel 7 menunjukkan nilai performance adalah sebesar $79 \%$, dimana nilai tersebut sama dengan nilai performance sebelum penerapan usulan 
perbaikan.

Selanjutnya dilakukan juga perhitungan untuk quality yang baru berdasardata pengamatan yang telah didapatkan. Data pada Tabel 8 menunjukan nilai quality adalah sebesar $94 \%$, dimana nilai tersebut lebih rendah daripada nilai quality sebelum penerapan usulan perbaikan.

Setelah didapatkan ketiga kategori penyusun OEE yang baru, langkah selanjutnya adalah melakukan perhitungan nilai OEE yang baru. Data pada Tabel 9 menunjukan nilai OEE adalah sebesar $60 \%$. Hal tersebut menunjukan nilai OEE yang baru meningkat sebesar 3\% dibandingkan OEE sebelum penerapan usulan perbaikan.

\section{KESIMPULAN}

Berdasarkan hasil identifikasi masalah menggunakan FMEA dan diagram Ishikawa terdapat 34 jenis potensi kegagalan dengan 39 efek kegagalan dan 44 penyebab kegagalan. Hal tersebut yang menyebabkan nilai OEE pada $\mathrm{CV}$. Gracia di tahun 2014 tergolong rendah. Pada penelitian kali ini dilakukan penerapan usulan perbaikan untuk memperbaiki nilai rata-rata OEE pada tahun 2014.

Penerapan yang dilakukan seperti pemindahan lokasi bahan baku ke posisi yang lebih dekat dengan mesin produksi membuat waktu tunggu menjadi lebih singkat, begitu juga dengan pembuatan katalog warna akan memberikan kemudahan bagi pekerja untuk mengatur komposisi warna yang diinginkan, sehingga waktu kerja dapat dibuat lebih efektif. Usulan perbaikan menghasilkan rata-rata nilai OEE yang baru adalah sebesar $60 \%$, dimana peningkatan terlihat pada kategori availability dengan demikian disimpulkan bahwa penerapan berdampak positif bagi perusahaan.

\section{DAFTAR PUSTAKA}

Carlson, C.S. 2012. Effective FMEAs: Achieving Safe, Reliable, and Economical Products and Processes Using Failure Mode and Effects Analysis. Hoboken: John Wiley\& Sons, Inc.

Gano, D. L. 2011. Seven Steps to Effective Problem-Solving and Strategies for Personal Success. Washington, USA: LLC Richland.

Montgomery, D. C. 2009. Introduction to Statistical Quality Control. Hoboken: John Wiley \& Sons, Inc.

Nakajima, S. 1988. Introduction to Total Productive Maintenance. Portland: Productivity Press Inc.
Rahmad, R,;Pratikto, P.; Wahyudi, S. 2012. "Penerapan overall equipment effectiveness (OEE) dalam implementasi total productive maintenance (TPM)". Jurnal Rekayasa Mesin, Vol. 3 (3), pp. 431-437.

Rinawati, D.I.; Dewi, N.C. 2014. "Analisis penerapan total productive maintenance (TPM) menggunakan overall equipment effectiveness (OEE) dan six big losses pada mesin Cavitec di PT. Essentra Surabaya." Prosiding SNATIF Ke-1 Tahun 2014, Kudus: Universitas Muria.

Said, A.; Susetyo, J.2008. "Analisis total producive maintenance pada lini produksi mesin perkakas guna memperbaiki kinerja perusahaan". Prosiding Seminar Nasional Aplikasi Sains dan Teknologi. Yogyakarta: IST Akprind. 